\title{
Embedded Yoga Technology
}

\author{
Kshitij Shinghal* \\ Department of Electronics \& Communication, MIT Moradabad, India
}

Submission: June 07, 2018; Published: June 19, 2018

*Corresponding author: Kshitij Shinghal, Associate Professor, Department of Electronics \& Communication, MIT Moradabad, Uttar Pradesh, India, Email: kshinghal@gmail.com

\section{Editorial}

It is my pleasure to write this editorial for Journal of yoga and Physiotherapy (JYP). The title of the article embedded yoga technology is a relatively new term, which means embedding yoga instructions ubiquitously in modern day technology equipment such as smart phones, laptops video games etc. There is a rapid and exponential increase in the number of physical disorders cases reported every year such as cervical spondylosis cases, degeneration of bones, back ache, neck ache, frozen shoulder. These problems which were earlier considered to be the problems associated with old age are now increasing among the youth specially among IT professionals, even children of small age group, due to the excessive use of smart phones, laptops, video games. The main cause for this is sitting for long durations in same posture, sitting in incorrect posture, working continuously on laptops computer without break etc. The "Embedded Yoga Technology" technique suggest that this is the high time to realize importance of yoga, meditation and physical exercise and include it in our daily life, making it part of our routine. In this technique the instructions of yoga will be embedded within the gadget such as smartphone, in its hardware or software. The gadget itself will give alerts/ messages to change posture or to take walk or to move shoulders or take short breaks etc. The alerts/cues can be visual display on screen, audible messages or vibrations etc. The embedded yoga instructions will vary as per the gadget for example for smart phone the instruction may be to take power walk while talking, not to sit in chin lock position while using Whatsapp, change fingers/thumb while browsing similarly for desktop user it may be to fix monitor above the eye level, take break after few minutes. If these instructions are embedded in gadgets and are displayed and announced intermittently users may follow the instructions and get benefitted. Truly the coming era is of modern day equipment like Amazon Echo, Google assistant etc. but if we do not take sufficient care this will turn the modernday generation in to more lethargic, suffering from various body ailments lack of enthusiasm and positive energy. Therefore, wise use of these equipment requires Embedded Yoga Technology.

The "Journal of Yoga and Physiotherapy (JYP)" is a very good platform for disseminating research work, ideas and innovations at internationally recognized platform. It is a multidisciplinary, international peer reviewed journal and is dedicated to promote spread the information in yoga and physiotherapy that seeks original research papers, review articles, mini- reviews, short communication, opinions, letters to editors etc. It invites papers related to yoga and physiotherapy. Yoga is the practice of attaining physical and mental health through meditation and physical exercise. Journal is dedicated to publish research in physiotherapy and spiritual practice followed in various regions of the world. The journal aims to publish original and clinically relevant research in topics related to Physiotherapy and other related fields in the health care community thus it promotes international readership. It focuses on international assembly for encouraging noble discussions and thus contributing for best treatment aids for the yoga and physiotherapy to the needy and also benefiting readers and authors by accelerating the dissemination of research information providing maximum access to advanced current academic and clinical information through Evidence based practice. It aims at rapid publication of high quality research, reviews and short communications and provides free access of the articles for the students, academicians, clinicians for future research. It also focuses on highest quality scientific papers and review articles of interest to academic and industrial researchers. The journal covers the entire range of topics related to Physiotherapy, from theoretical advances to relevant and sensible translations of a practical problem into a statistical framework, including advances in yoga and physiotherapy. Its main focus is on covering recent developments in areas of Yoga and Physiotherapy.

JYP opens the door for reproducible research allowing readers to easily replicate analysis described in papers. Please contribute articles to this journal in a timely manner, to ensure it gets published timely and becomes part of this important forum for the exchange of ideas and knowledge which will ultimately translate to better technological exchange of information among peers. If you have any questions or comments about the Journal, please contact at jyp@juniperpublishers.com, jyp@ juniperpublishers.org, jyp@juniperpublishers.us The Journal is available online, please visit the following website: http:// juniperpublishers.com/jyp/. 


\section{References and Acknowledgement}

I have based this paper on the materials collected from several courses I've attended. Some of this information is also featured in various tutorials available online. In addition, I have also consulted several web pages while writing this article. I would also like to thank Mr. Amit Saxena and Ms. Deepti Shinghal for their valuable support, without their help this article would have been impossible to complete.

This work is licensed under Creative Commons Attribution 4.0 License

DOI: 10.19080/JYP.2018.05.555657

\section{Author's Biography}

Kshitij Shinghal obtained his PhD in 2013 in the research field of VLSI Design and Wireless Sensor Network. He is now an Associate Professor with MIT Moradabad and is based in Moradabad, UP, India. His research areas of interest include Embedded Systems, VLSI Design, Biomedical Electronics, Wireless Sensor Networks, and Ad-Hoc Networks. He has published more than 100 research articles in International Journals and Conference Proceedings.

\section{Your next submission with Juniper Publishers will reach you the below assets}

- Quality Editorial service

- Swift Peer Review

- Reprints availability

- E-prints Service

- Manuscript Podcast for convenient understanding

- Global attainment for your research

- Manuscript accessibility in different formats

( Pdf, E-pub, Full Text, Audio)

- Unceasing customer service

Track the below URL for one-step submission

https://juniperpublishers.com/online-submission.php 